\title{
Ocular Manifestations of Patients with Coronavirus Disease 2019: A Comprehensive Review
}

\author{
Amirhossein Roshanshad 1,2, MD; Mohammad Ali Ashraf ${ }^{1,2}$, MD; Romina Roshanshad ${ }^{1,2}$, MD \\ Ali Kharmandar ${ }^{3,4}$, MD; Seyed Alireza Zomorodian¹, MD; Hossein Ashraf ${ }^{2}$, MD \\ ${ }^{1}$ Student Research Committee, Shiraz University of Medical Sciences, Shiraz, Iran \\ ${ }^{2}$ Poostchi Ophthalmology Research Center, Shiraz University of Medical Sciences, Shiraz, Iran \\ ${ }^{3}$ Non-communicable Disease Research Center, Fasa University of Medical Sciences, Fasa, Iran \\ ${ }^{4}$ Health Policy Research Center, Institute of Health, Shiraz University of Medical Sciences, Shiraz, Iran
}

ORCID:

Amirhossein Roshanshad: https://orcid.org/0000-0001-6725-0045

Hossein Ashraf: https://orcid.org/0000-0003-4429-1658

\section{Abstract}

Apart from conjunctival involvement which is the most well-known ocular manifestation of coronavirus infectious disease 2019 (COVID-19), there are multiple reports of the involvement of other ocular structures by severe acute respiratory syndrome coronavirus 2 (SARS-CoV-2). We comprehensively reviewed PubMed, Scopus, Embase, and Google Scholar for available evidence regarding COVID-19 various ocular manifestations, with special focus on less known and unusual ocular findings. We then categorized the findings based on the parts of the eye which was involved. In anterior sections of the eye, the involvement of the eyelid (tarsadenitis), conjunctiva and cornea (follicular conjunctivitis, pseudomembranous conjunctivitis, and keratoconjunctivitis), episclera (nodular episcleritis), uvea (anterior uveitis) were reported. Also, third, fourth, and sixth nerve palsy, retinal vasculitis, retinal optical coherence tomography (OCT) changes (hyper-reflective lesions and increased retinal nerve fiber layer thickness [RNFLT]), optic neuritis, papillophlebitis, Miller Fisher syndrome, posterior reversible leukoencephalopathy (PRES), ophthalmic artery and central retinal artery occlusion, and polyneuritis cranialis were reported in different studies. Postmortem evaluation of COVID-19 patients detected no viral RNA in different anterior and posterior segments of the eyes. However, another study revealed a $21.4 \%$ positivity of the retinal biopsies of dead patients. The results of this study can help ophthalmologists to be vigilant when they see these findings in a suspected case of COVID-19. In addition, wearing face masks and protective goggles or eye shields are recommended, especially in high risk contacts.

Keywords: Coronavirus; COVID-19; Manifestations; Ocular; Ophthalmologic

J Ophthalmic Vis Res 2021; 16 (2): 234-247 


\section{INTRODUCTION}

Since December 2019, coronavirus has caused more than 990,000 deaths and contamination of more than 32.7 million people globally till September 27, 2020. ${ }^{[1]}$ Coronavirus disease 2019 (COVID-19) can be transmitted directly through person to person contacts via droplets released during sneezing or coughing. Indirect transmission of severe acute respiratory syndrome coronavirus 2 (SARS-CoV-2) through surface contamination can be regarded as the second way of getting infected. ${ }^{[2-4]}$ In addition, SARS-CoV-2 has been detected in tears and conjunctival secretions of infected people. ${ }^{[5]}$ Therefore, adhering to personal hygiene principles is a fundamental part of COVID19 prevention, especially for healthcare workers.

Ophthalmologists are at high risk of contracting COVID-19 due to their close contact with the patients during routine ophthalmologic exams such as slit lamp examinations and direct ophthalmoscopy. ${ }^{[6]}$ Also, the patients' prolonged stay at ophthalmology clinics for multiple ophthalmology examinations imposes ophthalmologists and other patients at increased risk of COVID-19. ${ }^{[7]}$ A recent study revealed a high probability of contamination of environmental surfaces of ophthalmology clinics. ${ }^{[8]}$ Ocular presentations of COVID-19 usually occur about two weeks after the first symptoms. However, it can be the presenting finding of newly diagnosed COVID-19 patients, especially when the virus enters from the eye mucosa. ${ }^{[9]}$ Consequently, knowing the latest presentations of COVID-19 is crucial for every ophthalmologist. It helps ophthalmologists to consider COVID-19 as a possible causative agent when they see these findings.

Like SARS-CoV, angiotensin-converting enzyme 2 (ACE 2) receptor is the mediator of SARSCoV-2 for entering the host cells. ${ }^{[10-12]}$ ACE 2 receptor is expressed in different human tissue,



including the pulmonary system, proximal tubule of kidney and bladder urothelium, myocardial cells, esophagus, and ileum. ${ }^{[13]}$ In the eye, ACE 2 receptor expression is reported in the conjunctiva, limbus, cornea, retina, and aqueous humor. ${ }^{[14-17]}$ It was thought earlier that COVID-19 only involves conjunctiva, cornea, and tear. However, recent studies have revealed the involvement of the other eye structures, such as eyelid, episcleral, and retina. Therefore, we gathered available data about ocular manifestations of COVID-19, focusing on recently reported manifestations.

\section{METHODS}

We systematically searched four databases, including Medline (Pubmed), Scopus, Embase, and Google Scholar for articles about ocular manifestations of COVID-19. We used the following keywords for searching the databases : ("coronavirus" OR "covid-19" OR "2019-ncov" OR "sars-cov-2") AND ("ocular" OR "eye" OR "cornea" OR "conjunctivitis" OR "conjunctiva" OR "conjunctival" OR "congestion" OR "uvea" OR "uveitis" OR "retina" OR "retinal" OR "retinitis" OR "optic" OR "lens" OR "chemosis" OR "blepharitis" OR "ophthalmic" OR "ophthalmologic" OR "ophthalmoplegia" OR "ophthalmoparesis" OR "nerve palsy"). We also searched the references of the included studies for more relevant articles. The primary search was done on June 19, 2020 and was updated on August 27, 2020. The inclusion criteria were original articles about the ocular manifestations of COVID-19 patients. Case reports and case series, letters, and editorials were also included. Studies without any information about ocular manifestations of COVID-19 were excluded. Also, some of the studies reporting duplicate and repeated well-known ocular manifestations of COVID-19 were excluded, and the main focus was put on the less reported ophthalmologic presentations. Included studies were categorized in this study and divided based on the involved part of the eye.

This is an open access journal, and articles are distributed under the terms of the Creative Commons Attribution-NonCommercial-ShareAlike 4.0 License, which allows others to remix, tweak, and build upon the work non-commercially, as long as appropriate credit is given and the new creations are licensed under the identical terms.

How to cite this article: Roshanshad A, Ashraf MA, Roshanshad R, Kharmandar A, Zomorodian SA, Ashraf H. Ocular Manifestations of Patients with Coronavirus Disease 2019: A Comprehensive Review. J Ophthalmic Vis Res 2021;16:234-247. 
We used Joanna Briggs Institute (JBI)'s critical appraisal too ${ }^{[18]}$ to assess the risk of bias of the included studies. The scores were calculated as percentages and studies with scores of $>60 \%$ and $<30 \%$ of total scores were regarded as low- and high risk of bias, respectively. Title and abstract screening, data extraction and risk of bias assessment were done by two authors (AR and MA) independently and disagreements were checked by another author (RR).

As shown in Figure 1, a total of 5,288 studies were initially found after searching the databases according to the aforementioned search strategy. After title and abstract screening, 85 studies were chosen for full-text evaluation. Finally, 40 studies were matched with our inclusion criteria to enter the study. Conjunctival involvement and conjunctival and tear COVID-19 PCR positivity have been reported before. Furthermore, there are several reports of some rare ocular manifestations of COVID-19, which are unfamiliar to many ophthalmologists and physicians. Therefore, we summarized the conjunctival findings part in our study and focused more on the less reported and less known ocular manifestations. The findings of each part of the eye are discussed separately.

\section{Ocular Manifestations}

\section{Eyelid}

A woman from Wuhan, China, who presented with lower eyelid swelling, pain, and tenderness in the lateral canthus of the right eye was diagnosed as acute tarsadenitis. The patient had visited her parents who had tested positive for COVID-19 one day before the onset of these manifestations. Along with the resolution of tarsadenitis, the patient developed subconjunctival hemorrhage. Radiologic and PCR test results were in favor of COVID-19 infection. ${ }^{[19]}$ Another study reported multiple cases of chalazion in three ICU nurses and ten additional cases in a hospital in Paris. ${ }^{[20]}$ PCR results of the ICU nurses were negative. Because of the role of bacterial infection in eyelid disorders such as blepharitis and meibomian gland diseases, ${ }^{[21,22]}$ it is far from the mind that SARS-CoV-2 itself could be responsible for the observed tarsadenitis and chalazion. However, it is thought that the cluster of chalazion was mainly due to the occupational conditions while managing COVID-19 patients. Firstly, prolonged use of eye goggles and the following reduced eye blinking can facilitate the evaporation of the tear film and hardening of the meibomian gland secretions. Secondly, the use of some disinfectants for cleaning eye shields can be irritating for the eyes. ${ }^{[20]}$ Thirdly, due to the role of blood supply on fat synthesis, we hypothesize that impaired blood flow due to the hypercoagulable state in COVID-19 patients $^{[23]}$ can change the composition of meibomian gland secretions and predispose the eyes to bacterial infection and following meibomian gland infection and tarsadenitis. ${ }^{[24]}$ Summary of the findings of eyelid, ocular surface, uvea, episclera, and ocular motor nerves are presented in Table 1 .

\section{Ocular surface: conjunctiva and cornea}

Hyperemia, epiphora, increased secretion, chemosis, and follicular conjunctivitis are the main symptoms of conjunctival involvement with SARS-CoV-2. ${ }^{[25]}$ Based on the "Report of the WHO-China Joint Mission on Coronavirus Disease 2019 (COVID-19)," conjunctival congestion occurs in about $0.8 \%$ of COVID-19 patients. ${ }^{[26]}$ However, other studies showed higher rates. In Chen et al study, about 5\% of COVID-19 patients had conjunctival congestions, 15\% of whom as the initial presentations. Another study showed that 3.1\% of COVID-19 patients presented with conjunctivitis, $0.7 \%$ of whom as the first symptom of the disease. ${ }^{[27]} \mathrm{A}$ high prevalence of conjunctivitis was reported to be $32 \%$ in Wu et al's study. $^{[9]}$ A meta-analysis stated that the overall prevalence of conjunctivitis among COVID-19 patients is about $1.1 \%$. It also showed that this prevalence was $0.7 \%$ in non-severe cases and $3 \%$ in severe ones. ${ }^{[28]}$ Common ocular symptoms of conjunctival congestion are increased conjunctival secretion, ocular pain, photophobia, dry eye, and tearing. It was also shown that conjunctival congestion is higher in patients with more handeye contact. ${ }^{[29]}$

In another study, a patient presented with conjunctival hyperemia, secretion, follicles, petechiae, tarsal hemorrhages, and chemosis with easily removed yellowish membrane on the tarsal conjunctiva of the lower lids. He was diagnosed as pseudomembranous conjunctivitis and punctate keratitis. ${ }^{[30]}$ 


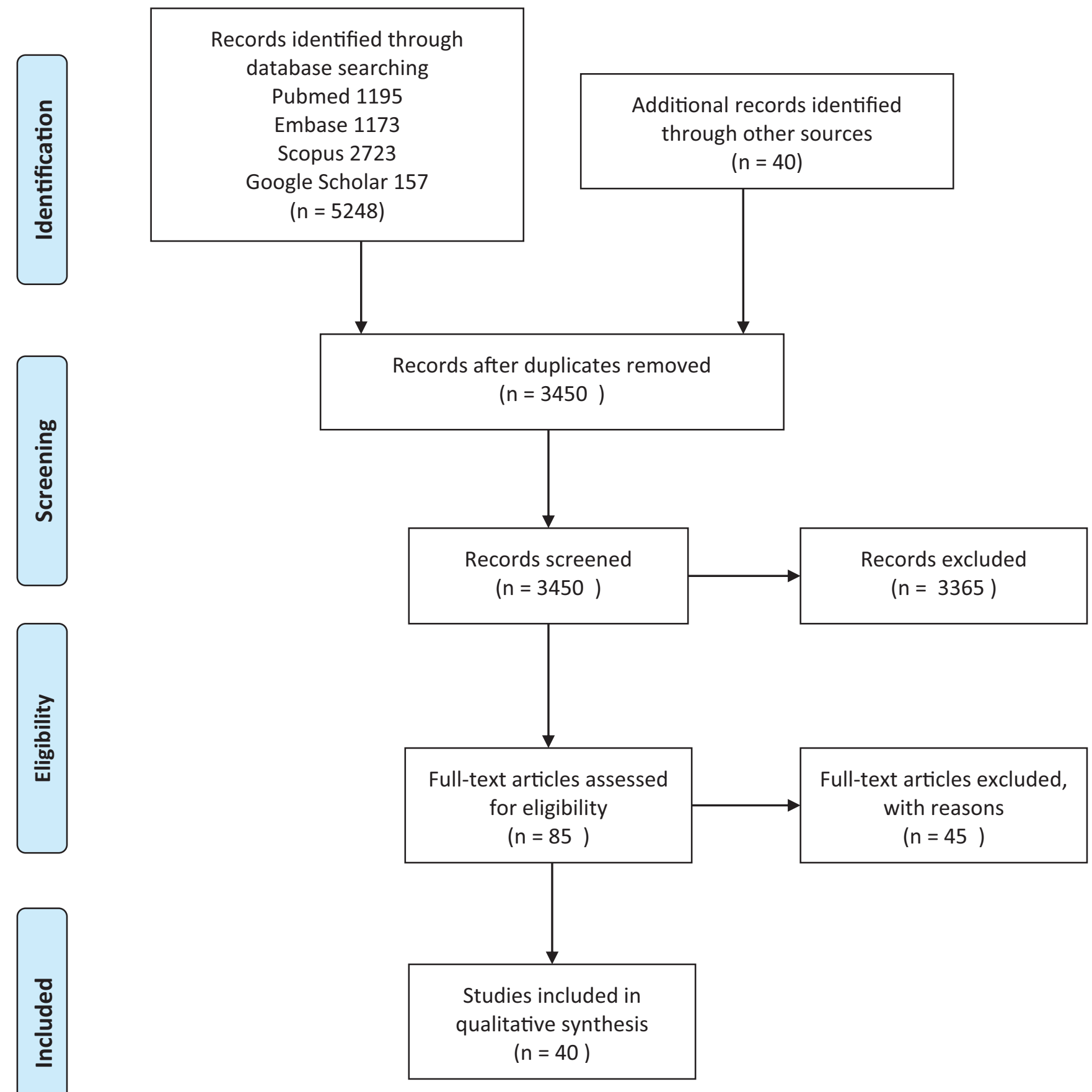

Figure 1. PRISMA flow chart of the screened and assessed articles.

Positive SARS-CoV-2 detection in conjunctival samples or ocular secretions has been reported in several studies. ${ }^{[31,32]}$ A systematic review showed that conjunctival/tear PCR samples were positive in about $2 \%$ of COVID-19 patients. ${ }^{[27]}$ Different studies revealed variation in positive PCR rate from 3 to $16 \%$, with an average of $5.8 \%$. $^{[3]}$
These variations may be due to the technical problems during collecting, keeping, and handling of the specimen, low viral load in the conjunctival secretion of some participants, and also the difference between the severity of the disease in different studies. ${ }^{[34,35]}$ 
Reminding the experience with SARS-CoV1 increased transmission during unprotected eye contacts, ${ }^{[36]}$ and possible transmission of SARS-CoV-2 through the conjunctiva, wearing protective goggles should become routine among healthcare workers with high risk contacts. ${ }^{[37]}$ It should be kept in mind that keratoconjunctivitis can be the initial manifestation of patients with COVID-19 infection. ${ }^{[38]}$ Therefore, first-line healthcare providers should ask questions regarding other manifestations of COVID-19 like fever and cough and a history of suspicious contact in patients presenting with a red eye. It is also revealed that conjunctival/tear PCR samples may be positive in some patients despite not having any ocular manifestations. ${ }^{[27]}$ It prompts the need for adherence to protective measures and wearing personal protective equipment even if no clinical symptoms are observed.

\section{Episcleral involvement}

A case of episcleritis was reported in Spain. A woman came with cough, myalgia, anosmia, and ageusia and had a positive PCR result for COVID-19. After these symptoms were resolved, she came to the ophthalmologic clinic with red eye, foreign-body sensation, epiphora, and photophobia, and nodular episcleritis was diagnosed. Besides, a study from Turkey revealed a $2.2 \%$ prevalence of episcleritis in COVID-19 patients. It was also shown that episcleritis was associated with a higher D-dimer level. ${ }^{[25]}$ The relationship between episcleritis and other viruses such as Ebola, HBV, HCV, and herpes zoster and immune-vascular factors and thrombotic complications of COVID-19 have risen the suspicion of the role of COVID-19 in developing episcleritis. ${ }^{[39]}$

\section{Glaucoma and uveitis}

A case of bilateral anterior uveitis following multisystem inflammatory syndrome in a COVID19 patient has been reported so far. $^{[40]}$ In addition, the involvement of uvea in other animals has been reported by other coronaviruses. ${ }^{[41,42]}$

To the best of our knowledge, no study has reported glaucoma as a presentation of COVID-19 yet. However, herpes virus detection in the trabecular meshwork and the following trabeculitis can result in intraocular pressure (IOP) elevation. ${ }^{[43]}$ Cytomegalovirus (CMV)-related anterior uveitis and the following rise of IOP in immunocompetent patients have been reported before, which is accompanied by the detection of CMV-DNA in aqueous humor. ${ }^{[44-47]}$ Hypertensive anterior uveitis can present with acute, recurrent, or chronic symptoms. By knowing the expression of ACE 2 receptor in aqueous humor ${ }^{[16]}$ and the role of CMV, herpes simplex virus, and Ebola virus in developing uveitic glaucoma, we can hypothesize the possible role of SARS-CoV2 in developing, exacerbation, or recurrence of glaucoma. ${ }^{[43,44,48]}$ Therefore, it is not far from the mind that there will be more reports of uvea involvement or glaucoma progression in the future. If so, ophthalmologists should consider COVID-19 infection in patients with suspicious symptoms of SARS-CoV-2 and recurrent rise of IOP.

\section{Ophthalmoparesis and nerve palsy}

Dinkin et al reported two cases with ophthalmoparesis after their COVID-19 PCR became positive. In the first case, the patient developed areflexia, third nerve palsy of the left eye, and sixth nerve palsy of the right eye, resulting from immune response to the virus or direct invasion of the virus and the following demyelination process. ${ }^{[49]}$ The second case presented with diplopia, abduction deficit, and optic nerve sheath enhancement of the right eye, suggesting optic nerve involvement. However, whether optic nerve involvement resulted from CNS invasion of the virus or it was only a coincidence is not clear. ${ }^{[50,51]}$ In spite of the intact abducens nerve in MRI, sixth nerve palsy could not be ruled out in this case.

In Falcone et al's study, a patient developed diplopia and abduction deficit three days after the onset of the respiratory symptoms. MRI findings showed lateral rectus atrophy and denervation, all of which favored complete abducens nerve palsy. ${ }^{[52]}$ Another study revealed bilateral trochlear nerve palsy in a COVID-19 patient with evidence of cerebral vasculitis in brain MRI. ${ }^{[53]}$ Overall, all of the aforementioned cranial nerve involvements can be the spectrum of neurological manifestations of COVID-19, caused by either direct involvement of 
Table 1. Characteristics and main findings of the included studies (eyelid, ocular surface, episcleral, uveal, and ocular motor nerve findings)

\begin{tabular}{ccccc}
\hline First author* & $\begin{array}{c}\text { Date of } \\
\text { publication }\end{array}$ & $\begin{array}{c}\text { Number } \\
\text { of cases }\end{array}$ & $\begin{array}{c}\text { Risk of } \\
\text { Bias }\end{array}$ & $\begin{array}{c}\text { Ocular } \\
\text { manifestations or } \\
\text { findings }\end{array}$
\end{tabular}

\section{Eyelid}

$\mathrm{Xu}^{[19]}$

April 2020

1

Medium

Pain in the lateral canthus and lower eyelid swelling

Megarbane $^{\dagger[20]}$ May $2020 \quad 3$ High Red eye, painless eyelid swelling, and tearing in three cases

\section{es} conjunctival redness without altered visual acuity or inflammatory nodules in the
middle of the lower eyelid, corneal abrasion

\section{Conjunctiva and cornea}

\begin{tabular}{|c|c|c|c|c|c|c|}
\hline $\begin{array}{l}\text { Bostanci } \\
\text { Ceran }^{[25]}\end{array}$ & June 2020 & 93 & Low & $\begin{array}{c}21 \% \text { of the patients } \\
\text { had ocular problems. } \\
\text { Photophobia }(16.1 \%), \\
\text { itchiness }(15.7 \%), \\
\text { burning sensation } \\
\text { (8.4\%), gritty feeling } \\
(6 \%), \text { blurred vision } \\
(4.8 \%)\end{array}$ & $\begin{array}{c}\text { Hyperemia (21.5\%), epiphora } \\
\text { (9.7\%), increased secretion } \\
(6.5 \%)\end{array}$ & $\begin{array}{l}\text { Chemosis (3.2\%), } \\
\text { follicular conjunctivitis } \\
\text { (8.6) }\end{array}$ \\
\hline $\mathrm{WHO}^{[26]}$ & $\begin{array}{l}\text { February } \\
2020\end{array}$ & 55,924 & $\mathrm{~N} / \mathrm{A}$ & & $\begin{array}{l}0.8 \% \text { of the patients had } \\
\text { conjunctival congestion }\end{array}$ & \\
\hline Loffredo $^{[28]}$ & April 2020 & 1,167 & Medium & & $\begin{array}{l}\text { Overall rate of conjunctivitis } \\
\text { was } 1.1 \% ; 0.7 \% \text { in non-severe } \\
\text { cases and } 3 \% \text { in severe cases }\end{array}$ & \\
\hline Chen $^{[29]}$ & May 2020 & 535 & High & $\begin{array}{c}\text { Increased } \\
\text { conjunctival secretion } \\
(9.7 \%) \text {, ocular pain } \\
(4.3 \%) \text {, photophobia } \\
(3 \%) \text {, dry eye }(21 \%) \\
\text { and tearing }(10.3 \%)\end{array}$ & $\begin{array}{l}5 \% \text { had conjunctival } \\
\text { congestion, } 15 \% \text { of whom as } \\
\text { the initial finding. Other } \\
\text { findings were: conjunctivitis } \\
(6.2 \%) \text {, xerophthalmia (4.5\%), } \\
\text { and keratitis }(2.6 \%)\end{array}$ & \\
\hline Navel ${ }^{[30]}$ & May 2020 & 1 & Low & $\begin{array}{l}\text { Follicles, petechias, } \\
\text { tarsal hemorrhages, } \\
\text { and chemosis }\end{array}$ & $\begin{array}{l}\text { Mucous filaments and tarsal } \\
\text { pseudomembranous }\end{array}$ & $\begin{array}{l}\text { Pseudomembranous } \\
\text { conjunctivitis }\end{array}$ \\
\hline Cheema $^{[38]}$ & April 2020 & 1 & Low & $\begin{array}{l}\text { Red eye, watery } \\
\text { discharge, } \\
\text { photophobia }\end{array}$ & $\begin{array}{l}\text { Conjunctival injection, } \\
\text { follicles, pseudodendrite in } \\
\text { the cornea, and subepithelial } \\
\text { infiltrates with overlying } \\
\text { epithelial defects at the } \\
\text { limbus }\end{array}$ & Keratoconjunctivitis \\
\hline $\mathrm{Wu}^{[9]}$ & & 38 & High & & $\begin{array}{c}31.6 \% \text { had ocular } \\
\text { manifestations consistent } \\
\text { with conjunctivitis including } \\
\text { hyperemia (7.9\%), chemosis } \\
\text { (21\%), epiphora (18.4\%), or } \\
\text { increased secretions (18.4\%) }\end{array}$ & \\
\hline
\end{tabular}

The same as symptoms

Single non-tender Single non-tender
flammatory nodules in the




Table 1. Continued)

\begin{tabular}{|c|c|c|c|c|c|c|}
\hline First author* & $\begin{array}{c}\text { Date of } \\
\text { publication }\end{array}$ & $\begin{array}{l}\text { Number } \\
\text { of cases }\end{array}$ & $\begin{array}{l}\text { Risk of } \\
\text { Bias }\end{array}$ & $\begin{array}{l}\text { Ocular } \\
\text { manifestations or } \\
\text { findings }\end{array}$ & Additional findings/Remarks & Diagnosis \\
\hline Sarma ${ }^{[27]}$ & April 2020 & 854 & Low & & $\begin{array}{l}3.2 \% \text { had conjunctivitis/red } \\
\text { eye, } 0.7 \% \text { reported } \\
\text { conjunctivitis as the first } \\
\text { symptom of the disease. } 2 \% \\
\text { positive conjunctival/tear } \\
\text { PCR samples }\end{array}$ & \\
\hline Chen $^{[31]}$ & April 2020 & 1 & Low & & $\begin{array}{l}\text { Positivity of conjunctival } \\
\text { swab specimens till } 19 \text { days } \\
\text { after the disease onset }\end{array}$ & Conjunctivitis \\
\hline Colavita $^{[32]}$ & $\begin{array}{c}\text { August } \\
2020\end{array}$ & 1 & Medium & $\begin{array}{l}\text { Higher viral load in } \\
\text { late ocular samples } \\
\text { than nasal swabs }\end{array}$ & $\begin{array}{c}\text { Positivity of ocular samples } \\
\text { till } 21 \text { days after the disease } \\
\text { onset }\end{array}$ & Conjunctivitis \\
\hline Aiello ${ }^{[33]}$ & May 2020 & 252 & Medium & & $\begin{array}{l}\text { 12/204 (5.8\%) had positive } \\
\text { PCR of conjunctival swab }\end{array}$ & \\
\hline
\end{tabular}

\section{Episclera}

Mendez

June $2020 \quad 1 \quad$ Low

Red eye, foreign-body Elevated epibulbar area with sensation, epiphora, Mangana ${ }^{[39]}$ and photophobia hyperemia at the inferotemporal sector without fluorescein defect

Bostanci June $202093 \quad$ Low
$2.2 \%$ of the patients had episcleritis

Nodular episcleritis

Ceran $^{[25]}$

June 2020

Low

\section{Uvea and Glaucoma}

Bettach $^{[40]} \quad$ June $2020 \quad 1 \quad$ Low Bilateral blurry vision

Conjunctival hyperemia, central corneal edema with Descemet's membrane folds, multiple keratic precipitates, and +1 anterior chamber cells and flare

\section{Ocular motor nerve}

Falcone ${ }^{[52]} \quad$ June $2020 \quad 1 \quad$ Medium Binocular diplopia
Dinkin $^{[49]} \quad$ May $2020 \quad 2 \quad$ High

de Oliveira $^{[53]} \quad$ June $2020 \quad 1 \quad$ Low

Case 1: ptosis, diplopia

Case 2: diplopia, abduction deficit

$\begin{array}{ccccc}\text { Falcone }^{[52]} & \text { June } 2020 & 1 & \text { Medium } & \text { Binocular diplopia } \\ \text { de Oliveira }^{[53]} & \text { June } 2020 & 1 & \text { Low } & \begin{array}{c}\text { Binocular diplopia } \\ \text { and occipital } \\ \text { headache }\end{array}\end{array}$

Case 1: mydriasis, ptosis and limited depression, adduction, and abduction Case 2: enhancement of the optic nerve sheaths and posterior Tenon capsules

Esotropia and limitation of abduction of the left eye. Atrophic left lateral rectus muscle in MRI

MRI showed vertebrobasilar system vasculitis, inflammation in the periaqueductal region and trochlear nuclei topography

Anterior uveitis

Case 1: third and sixth nerve palsy

Case 2: optic nerve involvement

Sixth nerve palsy

Fourth nerve palsy

\footnotetext{
*The studies are categorized based on the section of the eye involved in a study

$\dagger$ In this study, participants were three nurses working in a COVID-19 ICU but had negative PCR test results $\mathrm{N} / \mathrm{A}$, Not available
} 
Table 2. Characteristics and main findings of the included studies (retina, neuro-ophthalmology, thromboembolic, and postmortem findings)

\begin{tabular}{cccccc}
\hline First author* & $\begin{array}{c}\text { Date of } \\
\text { publication }\end{array}$ & $\begin{array}{c}\text { Number } \\
\text { of cases }\end{array}$ & $\begin{array}{c}\text { Risk of } \\
\text { Bias }\end{array}$ & $\begin{array}{c}\text { Ocular } \\
\text { manifestations or } \\
\text { findings }\end{array}$ & Additional findings/Remarks \\
& & \multicolumn{4}{c}{ Diagnosis }
\end{tabular}

\section{Retina}

$\begin{array}{llll}\text { Casagrande }^{[55]} & \text { May 2020 } & 14 & \text { Medium } \\ \text { Marinho }^{[56]} & \text { May 2020 } & 12 & \text { High }\end{array}$

Quintana- July $2020 \quad 1 \quad$ High

Castanedo ${ }^{[59]}$

$\begin{array}{lccc}\begin{array}{l}\text { Burgos- } \\ \text { Blasco }^{[60]}\end{array} & \text { July } 2020 & 5 & \text { Medium } \\ \begin{array}{l}\text { Insausti- } \\ \text { García }^{[61]}\end{array} & \text { July } 2020 & 1 & \text { Low } \\ \text { Raony }^{[62]} & \text { June } 2020 & 0 & \text { N/A }\end{array}$

\section{Neuro-ophthalmology}

\begin{tabular}{|c|c|c|c|c|}
\hline $\begin{array}{l}\text { Gutiérrez- } \\
\text { Ortiz }^{[70]}\end{array}$ & April 2020 & 2 & Medium & $\begin{array}{l}\text { Case 1: right INO and } \\
\text { fascicular oculomotor } \\
\text { palsy } \\
\text { Case } 2 \text { : bilateral } \\
\text { abducens palsy }\end{array}$ \\
\hline Lantos $^{[71]}$ & May 2020 & 1 & Low & $\begin{array}{l}\text { Left eye drooping, } \\
\text { blurry vision, reduced } \\
\text { sensation in both } \\
\text { legs, ataxia }\end{array}$ \\
\hline Kaya $^{[73]}$ & April 2020 & 1 & Medium & $\begin{array}{l}\text { Acute confusional } \\
\text { state, vision loss }\end{array}$ \\
\hline Doo ${ }^{\dagger[74]}$ & July 2020 & 2 & High & $\begin{array}{c}\text { Visually } \\
\text { asymptomatic }\end{array}$ \\
\hline
\end{tabular}

Positivity of retinal biopsy samples in 3 of 14 (21.4\%) COVID-19 patients

Hyper-reflective lesions in ganglion cell and inner plexiform layers more obvious at the papillomacular bundle, normal

OCT-angiography and ganglion cells complex analysis in all patients, cotton wool spots and microhemorrhages in four (33.3\%) patients

Retinal vasculitis on the asymptomatic equator of the left eye, one perivascular infiltrate, and extended retinal exudates

Seven out of eight (87.5\%) eyes showed an increase in RNFLT

Reduced sensitivity of Tortuous and dilated retinal the visual field in left vessels, retinal hemorrhages, eye and disc edema

Cytokine storm can aggravate retinal lesions in infected patients with DM. CD-147 may also facilitate retinal invasion of SARS-CoV-2

Case 1: albuminocytologic dissociation, positive GD1b-lgG antibodies

Case 2: albuminocytologic dissociation

Third cranial nerve enhancement and enlargement in MRI consistent with third nerve palsy, bilateral sixth nerve palsy decreased sensation below the knees to all modalities

MRI showed vasogenic edema similar to posterior reversible leukoencephalopathy (PRES) Papillo-phlebitis Retinal vasculitis Bilateral posterior cerebral vasogenic edema in one case
Case 1:MFS

Case 2: polyneuritis cranialis

MFS

PRES

PRES 
Table 2. Continued)

\begin{tabular}{|c|c|c|c|c|c|c|}
\hline First author* & $\begin{array}{c}\text { Date of } \\
\text { publication }\end{array}$ & $\begin{array}{l}\text { Number } \\
\text { of cases }\end{array}$ & $\begin{array}{l}\text { Risk of } \\
\text { Bias }\end{array}$ & $\begin{array}{l}\text { Ocular } \\
\text { manifestations or } \\
\text { findings }\end{array}$ & Additional findings/Remarks & Diagnosis \\
\hline Agarwal $^{\dagger[75]}$ & $\begin{array}{l}\text { August } \\
2020\end{array}$ & 115 & High & & $\begin{array}{l}\text { 30\% of COVID-19 patients } \\
\text { with brain MRI had } \\
\text { leukoencephalopathy and/or } \\
\text { cerebral microbleeds }\end{array}$ & \\
\hline Cariddi ${ }^{[76]}$ & June 2020 & 1 & High & $\begin{array}{l}\text { Blurred vision, altered } \\
\text { mental status }\end{array}$ & $\begin{array}{l}\text { Decreased nasolabial fold, } \\
\text { tone and strength of the legs, } \\
\text { and all deep tendon reflexes }\end{array}$ & PRES \\
\hline Parauda $^{\dagger[77]}$ & July 2020 & 4 & High & $\begin{array}{l}\text { Visually } \\
\text { asymptomatic }\end{array}$ & $\begin{array}{c}\text { Imaging showed cerebral } \\
\text { vasogenic edema in four } \\
\text { cases }\end{array}$ & PRES \\
\hline Zhou $^{[78]}$ & June 2020 & 1 & Medium & $\begin{array}{l}\text { Bilateral subacute } \\
\text { vision loss of both } \\
\text { eyes. Pain with eye } \\
\text { movements }\end{array}$ & $\begin{array}{l}\text { Bilateral disc edema and } \\
\text { venous congestion. Retinal } \\
\text { perivenous hemorrhages in } \\
\text { the right eye. Positive } \\
\text { MOG-IgG. Both optic nerve } \\
\text { enhancement }\end{array}$ & $\begin{array}{l}\text { Optic neuritis } \\
\text { associated with } \\
\text { MOG-lgG }\end{array}$ \\
\hline \multicolumn{7}{|c|}{ Thromboembolic events } \\
\hline Dumitrascu $^{[79]}$ & May 2020 & 1 & Medium & $\begin{array}{l}\text { Sudden onset vision } \\
\text { loss, no light } \\
\text { perception }\end{array}$ & $\begin{array}{l}\text { Retinal and optic disc edema, } \\
\text { retinal exudates, attenuated } \\
\text { retinal vessels, and absent } \\
\text { macular cherry-red spot }\end{array}$ & $\begin{array}{l}\text { Ophthalmic artery } \\
\text { occlusion }\end{array}$ \\
\hline Acharya $^{[80]}$ & June 2020 & 1 & High & $\begin{array}{l}\text { Sudden onset vision } \\
\text { loss }\end{array}$ & $\begin{array}{l}\text { Indistinct optic nerve } \\
\text { margins, cherry red spot, } \\
\text { significant retinal whitening }\end{array}$ & $\begin{array}{l}\text { Central retinal artery } \\
\text { occlusion }\end{array}$ \\
\hline \multicolumn{7}{|c|}{ Postmortem findings } \\
\hline Casagrande ${ }^{[55]}$ & May 2020 & 14 & Medium & & $\begin{array}{l}\text { Mentioned in the Retinal } \\
\text { findings part }\end{array}$ & \\
\hline Löffler $^{[86]}$ & June 2020 & 3 & High & & $\begin{array}{l}\text { Case 1: optic atrophy } \\
\text { Case 2: epiretinal gliosis, } \\
\text { retinal paving-stone and spot } \\
\text { bleeding, and drusen } \\
\text { Case 3: AMD, macular } \\
\text { atrophy, photoreceptor loss } \\
\text { of outer retina, choroid } \\
\text { thinning, and pinguecula }\end{array}$ & $\begin{array}{l}\text { Case 1: MS } \\
\text { Case 2: diabetic and } \\
\text { hypertensive } \\
\text { Case 3: Parkinsonism }\end{array}$ \\
\hline Bayyoud ${ }^{[87]}$ & June 2020 & 5 & Medium & & $\begin{array}{l}\text { No viral RNA in samples of } \\
\text { corneal stroma, endothelium } \\
\text { and epithelium, conjunctival } \\
\text { fluid swabs, bulbar-limbal } \\
\text { conjunctiva, anterior } \\
\text { chamber fluid }\end{array}$ & \\
\hline Bayyoud $^{[88]}$ & June 2020 & 1 & Low & & $\begin{array}{l}\text { No viral RNA in conjunctival } \\
\text { fluid swabs, bulbar } \\
\text { conjunctiva, corneal } \\
\text { epithelium, stroma, and } \\
\text { endothelium, anterior } \\
\text { chamber fluid, lens, iris, } \\
\text { vitreous, retina, uvea, sclera, } \\
\text { and optic nerve }\end{array}$ & \\
\hline Fuest $^{[89]}$ & July 2020 & 23 & Medium & & $\begin{array}{l}\text { No viral RNA in conjunctival } \\
\text { swabs }\end{array}$ & \\
\hline
\end{tabular}

*The studies are categorized based on the section of the eye involved in a study

$\dagger$ In these studies, the patients did not have any ophthalmologic findings or symptoms; however, due to the presence of ocular manifestations in some patients with PRES and leukoencephalopathy, the studies were included

INO, internuclear ophthalmoplegia; GD1b-IgG antibody, antibody against ganglioside complex GD1b; MOG, Myelin

Oligodendrocyte Glycoprotein; PRES, posterior reversible leukoencephalopathy; MFS, Miller Fisher syndrome; N/A, not available 
the CNS, excessive cytokine release, or endothelial dysfunction. ${ }^{[54]}$

\section{Retinal findings}

A study on retinal biopsies of 14 deceased patients with COVID-19 showed positivity of SARS-CoV-2 in three (21\%) of them. ${ }^{[55]}$ It is in line with the expression of ACE 2 receptor in the human retina. ${ }^{[15]}$ Another study evaluated retinal findings in COVID-19 patients. It revealed hyperreflective lesions at the level of ganglion cell and inner plexiform layers. Besides, four patients had microhemorrhages and cotton wool spots. Other ophthalmologic investigations, including OCT angiography and ganglion cells complex analysis, visual acuity, and pupillary reflexes, were normal. ${ }^{[56]}$ Due to the previous reports of retinitis in animals and these two reports, ${ }^{[57,58]}$ the involvement of retina by SARS-CoV-2 is expectable. Interestingly, a patient was diagnosed with retinal vasculitis without any ophthalmologic symptoms. ${ }^{[59]}$ However, because of the absence of a control group and low sample size in this study, it is hard to differentiate whether SARS-CoV-2 or incidental findings cause these findings.

Another study compared OCT findings of optic nerve before and after COVID-19 infection in eight eyes of five patients. This study revealed an overall increase in RNFLT in seven of eight eyes, which can result from optic nerve inflammation. ${ }^{[60]}$ Aggravation of retinal lesions in diabetic retinopathy and papillophlebitis were also attributed to SARS-CoV-2-induced cytokine storm and inflammatory process in two studies. ${ }^{[61,62]}$

In addition to the direct involvement of the retina by SARS-CoV-2, COVID-19 can alter the pattern of some retinal diseases. Studies showed that COVID-19 lockdown was associated with less or delayed presentation and diagnosis of retinal detachment ${ }^{[63]}$ and a higher prevalence of proliferative vitreoretinopathy, accompanied by a lower response to surgery. ${ }^{[64,65]}$ Summaries of the retinal, neuro-ophthalmologic, thromboembolic, and postmortem findings are presented in Table 2.

\section{Neuro-ophthalmologic manifestations}

Like SARS-CoV, CNS involvement is seen in COVID-19 infection due to the expression of ACE2 receptor in nervous tissue and high affinity of SARS-CoV and SARS-CoV-2 with this receptor. ${ }^{[66,67]}$ Guillain-Barré syndrome in COVID-19 patients has been reported in several studies. ${ }^{[51,68,69]}$ Also, Miller Fisher syndrome, a variant of Guillain-Barré syndrome presenting with ophthalmoplegia has been observed in COVID-19 infection. ${ }^{[70,71]}$ In Gutiérrez-Ortiz et al's study, the first patient presented with fascicular oculomotor palsy and internuclear ophthalmoparesis of the right eye, and the second patient had bilateral abducens nerve palsy. Both of them had albuminocytologic dissociation, areflexia, and positive oropharyngeal PCR swab test, and COVID-19 was confirmed. While the first patient was a Miller Fisher syndrome case, the second was diagnosed as polyneuritis cranialis. ${ }^{[70]}$ In another study, a case with a previous history of strabismus of the left eye presented with left oculomotor nerve palsy, and after workup, Miller Fisher syndrome was diagnosed. The nasopharyngeal PCR test was positive for COVID-19. MRI showed significant enlargement and enhancement of the third cranial nerve. Later, the patient manifested with bilateral abducens nerve palsy. ${ }^{\text {[71] }}$

In another study conducted by Kaya et al, a 38-year-old man was admitted due to COVID-19 developing with sudden onset vision loss. Brain MRI findings showed vasogenic edema similar to what is observed in PRES. The exact association between SARS-CoV-2 and PRES and the etiology of PRES is not clear in this study. However, due to the neurotropism of SARS-CoV-2, ${ }^{[72]}$ it is thought that PRES can be the result of direct invasion of the virus and the inflammatory process in the setting of COVID-19 infection. ${ }^{[73]}$ It should be mentioned that several other studies reported PRES as a rare presentation of COVID-19, especially in severely ill patients. ${ }^{[74-77]}$ The severity of vision loss varies significantly in these studies, ranging from blurred vision to severe vision loss detecting only hand motions.

We also found a report of optic neuritis associated with the Myelin Oligodendrocyte Glycoprotein (MOG) antibody and COVID-19 infection, which can be another aspect of the neuro-ophthalmologic manifestations of COVID$19 .^{[78]}$

\section{Thromboembolic event}

Dumitrascu et al presented the first ocular vascular complication of COVID-19. A 48-year-old 
obese man with severe COVID-19 infection and following upper and lower extremities DVTs was discharged from the hospital. Firstly, enoxaparin was administered for him, but later, it was changed to apixaban. One day after the apixaban start, he developed sudden onset vision loss of right eye without light perception and obvious relative afferent pupillary defect. Based on this history and a funduscopic examination, incomplete ophthalmic artery occlusion (OAO) was diagnosed. ${ }^{[9]}$ A case of central retinal artery occlusion was also reported in a patient with confirmed COVID-19 infection. Interestingly, contrary to the former case, no previous history of thrombotic events and anticoagulant consumption were reported for this patient. ${ }^{[80]}$

Due to the hypercoagulability state caused by COVID-19 infection, ${ }^{[81-83]}$ ophthalmologists should consider SARS-CoV-2 as a possible cause of OAO in patients with acute vision loss, especially in ones with underlying hypercoagulability state or thrombophilia. Also, more studies are needed to determine the optimal anticoagulant in COVID-19 patients to prevent such complications, especially in those with a hypercoagulable state. ${ }^{[84,85]}$

\section{Post-mortem findings}

In Löffler et al's study, three patients were evaluated for postmortem ocular findings. The findings were mainly due to their underlying diseases and conditions. For example, optic atrophy was found in a multiple sclerosis patient, and epiretinal gliosis, retinal paving-stone and spot bleeding, and drusen were observed in a diabetic hypertensive case. The third case, a 95year-old patient with Parkinsonism, presented with age-related macular degeneration (AMD), macular atrophy, photoreceptor loss of the outer retina, choroid thinning, and pinguecula; in addition, autolytic changes were seen in microscopic evaluation of three cases. In another study, three of 14 retinal samples were positive for SARS-CoV-2 RdRp-gene, E-gene, and Orf nCoV-gene-specific sequences, which is consistent with the existence of ACE 2 receptors in human retinal cells. ${ }^{[15,55,86]}$ However, due to the absence of data on examining these patients before COVID-19 infection, we cannot ensure that coronavirus did not have any role in the occurrence or aggravation of these presentations. Additionally, three other studies evaluated the SARS-CoV-2 positivity in different ocular tissues of 29 deceased patients, all of which were negative. ${ }^{[87-89]}$

Overall, it seems that there is a low risk of ocular tissue involvement by SARS-CoV-2. However, studies with more sample sizes are needed to confirm this assumption. These findings should be considered when designing ophthalmology practice guidelines and criteria for corneal donors in the COVID-19 era.

Other coronaviruses have been reported to cause pyogranulomatous anterior uveitis, optic neuritis, choroiditis with retinal detachment, and retinal vasculitis in animals. ${ }^{[41,42]}$ Due to the presence of ACE 2 receptors in the ciliary body, vitreous body, and Muller cells, ${ }^{[90,91]}$ there may be further reports of the involvement of ocular structures by SARS-CoV-2 not reported yet. It also prompts ophthalmologists to remain vigilant about ocular manifestations of COVID-19. Furthermore, adhering to eye hygiene principles not only reduces the risk of SARS-CoV-2 transmission through the eye, but also reduces the risk of dry eye, bacterial infections, and the following ocular disorders.

\section{Acknowledgment}

The authors would like to thank the Research Consultation Center (RCC) of Shiraz University of Medical Science for their assistance in revising the manuscript.

\section{Financial Support and Sponsorship}

This project was not funded or sponsored by any agency or organization.

\section{Conflicts of interest}

The authors have no competing interests to declare.

\section{REFERENCES}

1. Chou R, Dana T, Buckley DI, Selph S, Fu R, Totten AM. Epidemiology of and risk factors for coronavirus infection in health care workers. Ann Intern Med 2020;173:120-136.

2. Douglas KAA, Douglas VP, Moschos MM. Ocular manifestations of COVID-19 (SARS-CoV-2): a critical review of current literature. In vivo 2020;34:1619-1628.

3. Rothan HA, Byrareddy SN. The epidemiology and pathogenesis of coronavirus disease (COVID-19) outbreak. J Autoimmun 2020:102433. 
4. Santarpia JL, Rivera DN, Herrera VL, Morwitzer MJ, Creager HM, Santarpia GW, et al. Aerosol and surface contamination of SARS-CoV-2 observed in quarantine and isolation care. Sci Rep 2020;10:12732.

5. Xia J, Tong J, Liu M, Shen Y, Guo D. Evaluation of coronavirus in tears and conjunctival secretions of patients with SARS-CoV-2 infection. J medical virology 2020;92(??):589-594.

6. Lai THT, Tang EWH, Chau SKY, Fung KSC, Li KKW. Stepping up infection control measures in ophthalmology during the novel coronavirus outbreak: an experience from Hong Kong. Graefes Arch Clin Exp Ophthalmol 2020;258:1049-1055.

7. Cadet J. Harmless effects of sterilizing 222-nm far-UV radiation on mouse skin and eye tissues. Photochem Photobiol 2020;96:949-950.

8. Aytoğan $H$, Ayintap $E$, Y®lmaz NÖ. Detection of coronavirus disease 2019 viral material on environmental surfaces of an ophthalmology examination room. JAMA Ophthalmol 2020;138:990-993.

9. Wu P, Duan F, Luo C, Liu Q, Qu X, Liang L, et al. Characteristics of ocular findings of patients with coronavirus disease 2019 (COVID-19) in Hubei Province, China. JAMA Ophthalmol 2020;138:575.

10. Wan Y, Shang J, Graham R, Baric RS, Li F. Receptor recognition by the novel coronavirus from Wuhan: an analysis based on decade-long structural studies of SARS coronavirus. J Virol 2020;94:e00127-e00200.

11. Li W, Moore MJ, Vasilieva N, Sui J, Wong SK, Berne MA, et al. Angiotensin-converting enzyme 2 is a functional receptor for the SARS coronavirus. Nature 2003;426:450454.

12. Letko M, Marzi A, Munster V. Functional assessment of cell entry and receptor usage for SARS-CoV-2 and other lineage B betacoronaviruses. Nat Microbiol 2020;5:562569.

13. Zou X, Chen K, Zou J, Han P, Hao J, Han Z. Single-cell RNAseq data analysis on the receptor ACE2 expression reveals the potential risk of different human organs vulnerable to 2019-nCoV infection. Front Med 2020;14:185-192.

14. Zhou L, Xu Z, Castiglione GM, Soiberman US, Eberhart CG, Duh EJ. ACE2 and TMPRSS2 are expressed on the human ocular surface, suggesting susceptibility to SARS-CoV-2 infection. Ocul Surf 2020;18:537-544.

15. Senanayake Pd, Drazba J, Shadrach K, Milsted A, RunggerBrandle E, Nishiyama K, et al. Angiotensin II and its receptor subtypes in the human retina. Invest Ophthalmol Vis Sci 2007;48:3301-3311.

16. Holappa M, Valjakka J, Vaajanen A. Angiotensin (17) and ACE2,"the hot spots" of renin-angiotensin system, detected in the human aqueous humor. Open $J$ Ophthalmol 2015;9:28.

17. Collin J, Queen R, Zerti D, Dorgau B, Georgiou M, Djidrovski I, et al. Co-expression of SARS-CoV-2 entry genes in the superficial adult human conjunctival, limbal and corneal epithelium suggests an additional route of entry via the ocular surface. Ocul Surf 2020;19:190-200.

18. Critical appraisal tools I Joanna Briggs Institute [Internet]. Joannabriggs.org; 2020 [cited 2020 December 4]. Available from: https://joannabriggs.org/critical-appraisaltools
19. Xu M, Zhang $H$, Niu X. COVID-19 patient firstly visiting eye doctor due to tarsadenitis and subconjunctival hemorrhage: a case report. Zhonghua Shiyan Yanke Zazhi/Chinese Journal of Experimental Ophthalmology 2020;38:374-376.

20. Megarbane B, Tadayoni R. Cluster of chalazia in nurses using eye protection while caring for critically ill patients with COVID-19 in intensive care. Occup Environ Med 2020;77:584-585.

21. McCulley JP, Dougherty JM, Deneau DG. Classification of chronic blepharitis. Ophthalmology 1982;89:1173-1180.

22. McCulley JP, Dougherty J. Bacterial aspects of chronic blepharitis. Trans Ophthalmol Soc UK 1986;105:314-318.

23. Terpos E, Ntanasis-Stathopoulos I, Elalamy I, Kastritis $E$, Sergentanis TN, Politou $M$, et al. Hematological findings and complications of COVID-19. Am J Hematol 2020;95:834-847.

24. Knop E, Knop N, Millar T, Obata H, Sullivan DA. The international workshop on meibomian gland dysfunction: report of the subcommittee on anatomy, physiology, and pathophysiology of the meibomian gland. Invest Ophthalmol Vis Sci 2011;52:1938-1978.

25. Bostanci Ceran B, Ozates S. Ocular manifestations of coronavirus disease 2019. Graefes Arch Clin Exp Ophthalmol 2020;258:1959-1963.

26. WHO. Report of the WHO-China joint mission on coronavirus disease 2019 (COVID-19). WHO; 2020.

27. Sarma $P$, Kaur $H$, Kaur $H$, Bhattacharyya J, Prajapat $\mathrm{M}$, Shekhar N, et al. Ocular manifestations and tear or conjunctival swab PCR positivity for 2019-nCoV in patients with COVID-19: a systematic review and meta-analysis. SSRN 2020. Available from: https://ssrn.com/abstract= 3566161

28. Loffredo L, Pacella F, Pacella E, Tiscione G, Oliva A, Violi F. Conjunctivitis and COVID-19: a meta-analysis. J Med Virol 2020;92:1413-1414.

29. Chen L, Deng C, Chen X, Zhang X, Chen B, Yu H, et al. Ocular manifestations and clinical characteristics of 535 cases of COVID-19 in Wuhan, China: a cross-sectional study. Acta Ophthalmol 2020;98:e951-e959.

30. Navel V, Chiambaretta F, Dutheil F. Haemorrhagic conjunctivitis with pseudomembranous related to SARSCoV-2. Am J Ophthalmol Case Rep 2020:100735.

31. Chen L, Liu M, Zhang Z, Qiao K, Huang T, Chen M, et al. Ocular manifestations of a hospitalised patient with confirmed 2019 novel coronavirus disease. $\mathrm{Br} \mathrm{J}$ Ophthalmol 2020;104:748-751.

32. Colavita F, Lapa D, Carletti F, Lalle E, Bordi L, Marsella $P$, et al. SARS-CoV-2 isolation from ocular secretions of a patient with COVID-19 in Italy with prolonged viral RNA detection. Ann Int Med 2020;173:242-243.

33. Aiello F, Afflitto GG, Mancino R, Li J-PO, Cesareo M, Giannini C, et al. Coronavirus disease 2019 (SARS-CoV2) and colonization of ocular tissues and secretions: a systematic review. Eye 2020;34:1206-1211.

34. Corman VM, Landt O, Kaiser M, Molenkamp R, Meijer A, Chu DK, et al. Detection of 2019 novel coronavirus (2019-nCoV) by real-time RT-PCR. Eurosurveillance 2020;25:2000045.

35. Lin C, Ye R, Xia Y. A meta-analysis to evaluate the effectiveness of real-time PCR for diagnosing novel 
coronavirus infections. Genet Mol Res 2015;14:1563415641.

36. Raboud J, Shigayeva A, McGeer A, Bontovics E, Chapman M, Gravel D, et al. Risk factors for SARS transmission from patients requiring intubation: a multicentre investigation in Toronto, Canada. PLoS ONE 2010;5:e10717.

37. Qing H, Li Z, Yang Z, Shi M, Huang Z, Song J, et al. The possibility of COVID-19 transmission from eye to nose. Acta Ophthalmol 2020;98:e388.

38. Cheema M, Aghazadeh $\mathrm{H}$, Nazarali S, Ting A, Hodges $J$, McFarlane A, et al. Keratoconjunctivitis as the initial medical presentation of the novel coronavirus disease 2019 (COVID-19). Can J Ophthalmol 2020;55:e125-e129.

39. Mendez Mangana C, Barraquer Kargacin A, Barraquer RI. Episcleritis as an ocular manifestation in a patient with COVID-19. Acta Ophthalmol 2020;98:e1056-e1057.

40. Bettach E, Zadok D, Weill Y, Brosh K, Hanhart J. Bilateral anterior uveitis as a part of a multisystem inflammatory syndrome secondary to COVID-19 infection. J Med Virol 2020;93:139-140.

41. Doherty M. Ocular manifestations of feline infectious peritonitis. Amer Vet Med Ass J 1971;159:417-424.

42. Seah I, Agrawal R. Can the coronavirus disease 2019 (COVID-19) affect the eyes? A review of coronaviruses and ocular implications in humans and animals. Ocul Immunol Inflamm 2020;28:391-395.

43. Amano S, Oshika T, Kaji Y, Numaga J, Matsubara M, Araie M. Herpes simplex virus in the trabeculum of an eye with corneal endotheliitis. Am J Ophthalmol 1999;127:721-722.

44. Carmichael A. Cytomegalovirus and the eye. Eye 2012;26:237-240.

45. Choi JA, Kim KS, Jung Y, Park HYL, Park CK. Cytomegalovirus as a cause of hypertensive anterior uveitis in immunocompetent patients. J Ophthalmic Inflamm Infect 2016;6:32.

46. Chee S, Jap A. Cytomegalovirus anterior uveitis: outcome of treatment. Br J Ophthalmol 2010;94:1648-1652.

47. Accorinti M, Gilardi M, Pirraglia M, Amorelli G, Nardella C, Abicca I, et al. Cytomegalovirus anterior uveitis: long-term follow-up of immunocompetent patients. Graefes Arch Clin Exp Ophthalmol 2014;252:1817-1824.

48. Varkey JB, Shantha JG, Crozier I, Kraft CS, Lyon GM, Mehta AK, et al. Persistence of Ebola virus in ocular fluid during convalescence. N Engl J Med 2015;372:2423-2427.

49. Dinkin M, Gao V, Kahan J, Bobker S, Simonetto M, Wechsler P, et al. COVID-19 presenting with ophthalmoparesis from cranial nerve palsy. Neurology 2020;95:221-223.

50. Gala F. Magnetic resonance imaging of optic nerve. Indian J Radiol Imaging 2015;25:421.

51. Zhao H, Shen D, Zhou H, Liu J, Chen S. Guillain-Barré syndrome associated with SARS-CoV-2 infection: causality or coincidence? Lancet Oncol 2020;19:383-384.

52. Falcone MM, Rong AJ, Salazar H, Redick DW, Falcone $\mathrm{S}$, Cavuoto KM. Acute abducens nerve palsy in a patient with the novel coronavirus disease (COVID-19). J AAPOS 2020;24:216-217.

53. de Oliveira RDMC, Santos DH, Olivetti BC, Takahashi JT. Bilateral trochlear nerve palsy due to cerebral vasculitis related to covid-19 infection. Arquivos de NeuroPsiquiatria 2020;78:385-386.
54. Chwalisz BK, Dinkin MJ. Disease of the year: COVID-19 and its neuro-ophthalmic complications. J Neuroophthalmol 2020;40:283-284.

55. Casagrande M, Fitzek A, Puschel K, Aleshcheva G, Schultheiss HP, Berneking L, et al. Detection of SARSCoV-2 in human retinal biopsies of deceased COVID-19 patients. Ocul Immunol Inflamm 2020;28:721-725.

56. Marinho PM, Marcos AAA, Romano AC, Nascimento $H$, Belfort R Jr. Retinal findings in patients with COVID-19. Lancet 2020;395:1610.

57. Seah I, Agrawal R. Can the coronavirus disease 2019 (COVID-19) affect the eyes? A review of coronaviruses and ocular implications in humans and animals. Ocul Immunol Inflamm 2020;28:391-395.

58. Wang Y, Detrick B, Yu Z-X, Zhang J, Chesky L, Hooks $\mathrm{JJ}$. The role of apoptosis within the retina of coronavirusinfected mice. Invest Ophthalmol Vis Sci 2000;41:30113018.

59. Quintana-Castanedo L, Feito-Rodríguez M, FernándezAlcalde C, Granados-Fernández M, Montero-Vega D, Mayor-lbarguren A, et al. Concurrent chilblains and retinal vasculitis in a child with COVID-19. J Eur Acad Dermatol Venereol 2020;34:e764-e766.

60. Burgos-Blasco B, Güemes-Villahoz N, Donate-Lopez J, Vidal-Villegas B, García-Feijóo J. Optic nerve analysis in COVID-19 patients. J Med Virol 2020;93:190-191.

61. Insausti-García A, Reche-Sainz JA, Ruiz-Arranz C, López Vázquez Á, Ferro-Osuna M. Papillophlebitis in a COVID19 patient: inflammation and hypercoagulable state. Eur J Ophthalmol 2020:1120672120947591.

62. Raony Í, Saggioro de Figueiredo C. Retinal outcomes of COVID-19: possible role of CD147 and cytokine storm in infected patients with diabetes mellitus. Diabetes Res Clin Pract 2020;165:108280.

63. Rohl A, Kalhorn A, Singh J, Mandava N. Decreased retinal detachments during a COVID-19 lockdown period in Colorado. Acta Ophthalmol 2020. Available from: https: //doi.org/10.1111/aos.14570

64. Awad M, Poostchi A, Orr G, Kumudhan D, Zaman A, Wilde C. Delayed presentation and increased prevalence of proliferative vitreoretinopathy for primary rhegmatogenous retinal detachments presenting during the COVID-19 pandemic lockdown. Eye 2020:1-2.

65. Poyser A, Deol SS, Osman L, Sivagnanasithiyar T, Kuht HJ, Manrique R, et al. Impact of COVID-19 pandemic and lockdown on retinal detachments. Eye 2020:1-2.

66. Netland J, Meyerholz DK, Moore S, Cassell M, Perlman S. Severe acute respiratory syndrome coronavirus infection causes neuronal death in the absence of encephalitis in mice transgenic for human ACE2. J Virol 2008;82:72647275.

67. Wrapp D, Wang N, Corbett KS, Goldsmith JA, Hsieh C-L, Abiona O, et al. Cryo-EM structure of the 2019-nCoV spike in the prefusion conformation. Science 2020;367:12601263.

68. Toscano G, Palmerini F, Ravaglia S, Ruiz L, Invernizzi P, Cuzzoni MG, et al. Guillain-Barré syndrome associated with SARS-CoV-2. N Engl J Med 2020;382:2574-2576.

69. Nordvig AS, Rimmer KT, Willey JZ, Thakur KT, Boehme AK, Vargas WS, et al. Potential neurological manifestations of COVID-19. Neurol Clin Pract 2020. Available from: https: //doi.org/10.1212/CPJ.0000000000000897 
70. Gutiérrez-Ortiz C, Méndez A, Rodrigo-Rey S, San PedroMurillo E, Bermejo-Guerrero L, Gordo-Mañas R, et al. Miller Fisher Syndrome and polyneuritis cranialis in COVID-19. Neurology 2020;95:e601-e605.

71. Lantos JE, Strauss SB, Lin E. COVID-19-associated Miller Fisher Syndrome: MRI findings. AJNR 2020;41:1184-1186.

72. Conde G, Pájaro LDQ, Marzola IDQ, Villegas YR, Salazar LRM. Neurotropism of SARS-CoV 2: Mechanisms and manifestations. J Neurol Sci 2020;412:116824.

73. Kaya Y, Kara S, Akinci C, Kocaman AS. Transient cortical blindness in COVID-19 pneumonia; a PRES-like syndrome: Case report. J Neurol Sci 2020;413:116858.

74. Doo FX, Kassim G, Lefton DR, Patterson S, Pham $\mathrm{H}$, Belani P. Rare presentations of COVID-19: PRESlike leukoencephalopathy and carotid thrombosis. Clin Imaging 2020.

75. Agarwal S, Jain R, Dogra S, Krieger P, Lewis A, Nguyen V, et al. Cerebral microbleeds and leukoencephalopathy in critically III patients with COVID-19. Stroke 2020;51:2649_ 2655.

76. Cariddi LP, Damavandi PT, Carimati F, Banfi P, Clemenzi A, Marelli M, et al. Reversible Encephalopathy Syndrome (PRES) in a COVID-19 patient. J Neurol 2020;267:31573160.

77. Parauda SC, Gao V, Gewirtz AN, Parikh NS, Merkler $\mathrm{AE}$, Lantos J, et al. Posterior reversible encephalopathy syndrome in patients with COVID-19. J Neurol Sci 2020;416:117019.

78. Zhou S, Jones-Lopez EC, Soneji DJ, Azevedo CJ, Patel VR. Myelin Oligodendrocyte glycoprotein antibody-associated optic neuritis and myelitis in COVID-19. J Neuroophthalmol 2020;40:398-402.

79. Dumitrascu OM, Volod O, Bose S, Wang Y, Biousse $\mathrm{V}$, Lyden PD. Acute ophthalmic artery occlusion in a COVID-19 patient on apixaban. J Stroke Cerebrovasc Dis 2020;29:104982.

80. Acharya S, Diamond M, Anwar S, Glaser A, Tyagi P. Unique case of central retinal artery occlusion secondary to COVID-19 disease. ID Cases 2020;21:e00867.

81. Giannis D, Ziogas IA, Gianni P. Coagulation disorders in coronavirus infected patients: COVID-19, SARS-CoV1, MERS-CoV and lessons from the past. J Clin Virol 2020;127:104362.
82. Tang N, Bai H, Chen X, Gong J, Li D, Sun Z. Anticoagulant treatment is associated with decreased mortality in severe coronavirus disease 2019 patients with coagulopathy. $J$ Thromb Haemost 2020;18:1094-1099.

83. Han H, Yang L, Liu R, Liu F, Wu K-I, Li J, et al. Prominent changes in blood coagulation of patients with SARS-CoV2 infection. Clin Chem Lab Med 2020;1(ahead-of-print).

84. Barnes GD, Burnett A, Allen A, Blumenstein M, Clark NP, Cuker A, et al. Thromboembolism and anticoagulant therapy during the COVID-19 pandemic: interim clinical guidance from the anticoagulation forum. J Thromb Thrombolysis 2020;50:72-81.

85. Barrett CD, Moore HB, Yaffe MB, Moore EE. ISTH interim guidance on recognition and management of coagulopathy in COVID-19: a comment. J Thromb Haemost 2020;18:2060-2063.

86. Löffler KU, Reinhold A, Herwig-Carl MC, Tzankov A, Holz FG, Scholl HPN, et al. Ocular post-mortem findings in patients having died from COVID-19. Ophthalmologe 2020;117:648-651.

87. Bayyoud T, Iftner A, Iftner T, Bartz-Schmidt KU, Rohrbach JM, Ueffing M, et al. Absence of Severe Acute Respiratory Syndrome-Coronavirus-2 RNA in human corneal tissues. Cornea 2020;40:342-347.

88. Bayyoud T, Iftner A, Iftner T, Bartz-Schmidt KU, Ueffing M, Schindler M, et al. Absence of Severe Acute Respiratory Syndrome-Coronavirus-2 RNA in ocular tissues. Am J Ophthalmol Case Rep 2020;19:100805.

89. Fuest M, Boor P, Knuechel R, Walter P, Salla S. Postmortem conjunctival and nasopharyngeal swabs in SARS-CoV-2 infected and uninfected patients. Acta Ophthalmol 2020.

90. Luhtala S, Vaajanen A, Oksala O, Valjakka J, Vapaatalo $\mathrm{H}$. Activities of angiotensin-converting enzymes ACE1 and ACE2 and inhibition by bioactive peptides in porcine ocular tissues. J Ocul Pharmacol Ther 2009;25:23-28.

91. Tikellis C, Johnston C, Forbes JM, Burns WC, Thomas $M C$, Lew RA, et al. Identification of angiotensin converting enzyme 2 in the rodent retina. Curr Eye Res 2004;29:419427. 